\title{
School nutrition program: Assessment of planning and nutritional recommendations of menus
}

\section{Programa de nutrición escolar: Evaluación de la planificación y recomendaciones nutricionales de los menús}

\section{ABSTRACT}

The aim of this study was to verify whether the portion sizes adopted by school lunch cooks were in accordance with nutritional recommendations by PNAE (Brazilian School Nutrition Program). Portion sizes corresponding to shallow and full measures were weighed on a digital scale in duplicate to determine the average weight of each food portion. Nutritional composition of meals was determined using the Brazilian Table of Food Composition. Total energy value (TEV), carbohydrates, proteins, lipids, iron, sodium, vitamin $C$ and dietary fiber were compared with PNAE recommendations for schoolchildren. As a result, two menu proposals with adequate portion sizes were developed. TEV and carbohydrate recommendations were met in the shallow portion size and exceeded recommendations in the full measure. Both shallow and full portions exceeded recommendations for protein, fat and sodium. The values found for dietary fiber, iron and vitamin $C$ were in accordance with PNAE recommendations in both portion sizes. The menu proposals were in accordance with nutritional recommendations except for sodium, which remained slightly above limits. The study showed the need for the creation of manufacturing technical cards aimed at standardizing the portioning of foods/dishes offered to schoolchildren, as well as the training of school lunch cooks.

Keywords: Brazilian school nutrition program, schoolchildren, menus, nutritional recommendations.

\section{INTRODUCTION}

Adequate and healthy food is a right of all basic education students - preschool, elementary school, high school and adult education - from public and philanthropic schools and community entities in partnership with the government. In Brazil, this right is guaranteed by the Brazilian School Nutrition Program (PNAE), which encourages the promotion of healthy eating habits in schools through the preparation of menus containing a variety of healthy safe foods, respecting the culture and traditions of the target population'.

Qualitatively and quantitatively, adequate food is essential
Roseane Moreira Sampaio, Maria BeatrizCabral Coutinho, Daniele Mendonça, Daniele da Silva Bastos, Patricia Henriques, Patricia Camacho, Alexandra Anastácio, Silvia Pereira.

1. Emília de Jesus Ferreiro Nutrition School. Department of Social Nutrition. Fluminense Federal University. Rio de Janeiro, Brazil. CEP: 24020-140. Niterói, Brazil

All authors contributed to the design, analysis and interpretation of results and critical analysis of the manuscript. All have approved the final version of the manuscript

Dirigir correspondencia a: Roseane Moreira Sampaio Barbosa. Rua Correa Dutra 117/402 - CEP: 22210-050. Rio de Janeiro - Brazil roseanesampaio@id.uff.br

Este trabajo fue recibido el 19 de enero de 2017 aceptado con modificaciones el 4 de abril de 2017 y aceptado para su publicación el 28 de abril de 2017.

to the growth and development of individuals ${ }^{2}$. In addition, school stage is characterized as the stage of life in which the incorporation of eating habits will influence dietary patterns into adulthood ${ }^{3}$.

A properly planned school menu should cover part of the nutritional needs of students during the school year, ensuring a proper and healthy diet is characteristic of the Food and Nutrition Education (FNE) and is considered a pedagogical element ${ }^{1}$. School menus should be developed by a dietitian affiliated with PNAE and follow its guidelines.

For a school menu to meet the nutritional needs of 
schoolchildren, school lunch cooks should perform the proper portioning of preparations according to the different age groups of students. The aim of this study was to verify whether menus offered in a municipal school are in accordance with the planning and nutritional recommendations of PNAE and to propose food preparations that meet the nutritional requirements recommended by the program.

\section{MATERIALS AND METHODS}

This cross-sectional study was conducted in a School Food and Nutrition Unit (SFNU) of a public educational institution of the state of Rio de Janeiro for five non-consecutive days in April 2015.

Data collection was carried out with 290 students in the morning, of these, an average of 240 students have lunch every day at the school, according to information collected at school. The distribution of lunch meals occurs in over the course of 60 minutes, depending on the number of students who will have lunch that day.

For data collection, the menu offered at the SFNU to schoolchildren aged 6-10 years was compared to that planned by the responsible dietitian of the Education Municipal Foundation of Rio de Janeiro for those days. The substitutions of foods/preparations encountered were questioned by the research team and the justifications presented by school lunch cooks were recorded on a specific form.

Analysis of meals was performed by direct observation of food sizes performed by school lunch cooks. This process has been carefully conducted for all food preparations.

For the analysis of the food supply, school lunch cooks were asked to perform the portioning of shallow and full measures of each preparation/food in four separate plates (two for each measure). With the aid of a digital scale (Plenna $($ ) with maximum capacity of $2 \mathrm{~kg}$ and precision of $0.01 \mathrm{~g}$, the portions corresponding to both measures (shallow and full) were weighed in duplicate to determine the average weight of each food portion. Data collected were recorded on a specific form.

The analysis of the nutritional composition of meals served was determined using the Brazilian Table of Food Composition ${ }^{4}$. Total energy value (TEV) (Kcal), carbohydrates (g) proteins (g), lipids (g), iron (g), sodium (mg) Vitamin C (mg) and dietary fiber (g) were compared with PNAE recommendations for children aged 6-10 years ${ }^{1}$. The amount of oil and cooking salt present in food portions were estimated from the total of these ingredients used in the preparation of meals in SFNU.

The average shallow and full measures were compared with the recommendation of $20 \%$ of nutritional requirements assigned for lunch for schoolchildren.

As a result of this study, two menu proposals for school cafeterias were developed. The adequate portioning of foods / preparations to be offered to students was determined based on nutritional recommendations established by PNAE'. Portion sizes used were obtained in the Table for Food Consumption Assessment in Home Food Measures ${ }^{5}$, based on kitchen utensils available at UANE.
In order to guide school lunch cooks regarding the proper portioning of meals, a food substitution list considering the main preparations used in the school meal planning was prepared.

This study was approved by the Research Ethics Committee of the Faculty of Medicine, Antonio Pedro University Hospital under Certificate of Presentation for Ethical Appreciation (CAAE) number: 3620.0.000.258-10.

\section{RESULTS}

Table 1 shows that the menu used in the school showed changes in relation to the menu planned by the technical staff of the municipality in all days observed, especially the last two days, which had three modified preparations / foods. The absence of garnish in three of the five days analyzed was observed, on the first day, there was no supply of vegetables, and on the other two days, vegetables were added to the main dish, not being considered garnish. We also found that there was no variety in the fruits offered in both menus. According to school lunch cooks, the distribution of meals was made based on the demands of students, such that children can ask for "a lot" or "a little". Daily contact between school lunch cooks and students allowed them to know the habits and food preferences of each student, as well as the portions to be offered, often without being requested (a lot or a little). Therefore, they use two measures to supply the meal: shallow or full plate.

Preparations/foods to be distributed to the age group studied (6-10 years) were portioned by cooks, namely: 1 serving spoon of rice, $1 / 2$ spoon of beans. Children who ate greater amounts received twice these measures, except for the main course, which remains the same. Some children do not eat the main course and just ask for the accompaniments. Fruits were offered every day in the self-service system, but there was no supervision in relation to their consumption.

Table 2 shows the averages of shallow and full measures in the five days analyzed, as well as the PNAE recommendations for schoolchildren. Regarding the TEV of meals, it was observed that the average value of the shallow portion met PNAE recommendation; however, the full portion exceeded recommendation. Considering shallow and full measures, both portions exceeded recommendations for this age group for both protein and lipids. The recommendation of carbohydrates was met in the portion related to the shallow measure, but exceeded up to double, the recommendation in the full measure. Dietary fiber, iron and vitamin $C$ values met PNAE recommendations both for portions related to the shallow measure as for portions related to the full measure. Sodium exceeded maximum recommendation established by PNAE in both portions.

In order to adjust the amounts of macronutrients and micronutrients found to quantities recommended for schoolchildren, an adequate meal was calculated, with standardized foods/preparations - regardless of shallow or full measures - based on observed meals. Two different menus were created, as shown in Table 3, both containing 


\section{TABLE 1}

Comparison of the planned menu with actual menu for the five days analyzed.

\begin{tabular}{|c|c|c|}
\hline Day & Planned menu & Actual menu \\
\hline 1 (Thursday) & $\begin{array}{l}\text { Rice, black beans, chicken leg and cauliflower salad; } \\
\text { dessert - orange. }\end{array}$ & $\begin{array}{l}\text { Rice, black beans and chicken leg; dessert } \\
\text { orange. }\end{array}$ \\
\hline 2 (Monday) & $\begin{array}{l}\text { Rice, black beans, tuna salad with potato and } \\
\text { mayonnaise; dessert - orange. }\end{array}$ & $\begin{array}{l}\text { Rice, black beans, tuna salad with potato } \\
\text { and mayonnaise; dessert - pineapple. }\end{array}$ \\
\hline 3 (Thursday) & $\begin{array}{l}\text { Rice, black beans, minced meat and braised cabbage; } \\
\text { dessert- papaya }\end{array}$ & $\begin{array}{l}\text { Rice, black beans, minced meat and } \\
\text { cauliflower; dessert - banana. }\end{array}$ \\
\hline 4 (Tuesday) & $\begin{array}{l}\text { Rice, black beans, goulash, potato puree; dessert - } \\
\text { tangerine }\end{array}$ & $\begin{array}{l}\text { Rice black beans, jerked beef with braised } \\
\text { pumpkin; dessert - banana. }\end{array}$ \\
\hline 5 (Friday) & $\begin{array}{l}\text { Rice beans, barbecue meat, lettuce salad and toasted } \\
\text { manioc flour; dessert - orange }\end{array}$ & $\begin{array}{l}\text { Rice with carrots, black beans, bull's liver; } \\
\text { dessert - orange. }\end{array}$ \\
\hline
\end{tabular}

\section{TABLE 2}

Amount of macronutrients, dietary fiber, iron, sodium and vitamin $\mathrm{C}$ of shallow and full measures of preparations/foods in the 5 days observed.

\begin{tabular}{|c|c|c|c|c|c|c|c|c|c|c|c|c|c|c|c|}
\hline $\begin{array}{l}\text { Day } \\
\text { Portion size }\end{array}$ & $\begin{array}{c}\text { Day } 1 \\
\text { Shallow }\end{array}$ & Full & $\begin{array}{l}\text { Day } 2 \\
\text { Shallow }\end{array}$ & Full & $\begin{array}{l}\text { Day } 3 \\
\text { Shallow }\end{array}$ & Full & $\begin{array}{l}\text { Day } 4 \\
\text { Shallow }\end{array}$ & v Full & $\begin{array}{l}\text { Day } 5 \\
\text { Shallow }\end{array}$ & N Full & $\begin{array}{l}\text { Shall } \\
\text { Mean }\end{array}$ & ${ }_{\text {SD }}^{\text {ow }}$ & $\begin{array}{c}\text { Fu } \\
\text { Mean }\end{array}$ & SD & PNAE \\
\hline Energy (kcal) & 465.9 & 715.9 & 392.4 & 883.4 & 334.7 & 586.4 & 325.1 & 528.9 & 301.6 & 518.6 & 363.9 & 66.0 & 646.6 & 153.9 & 300 \\
\hline Protein (g) & 38.3 & 53.5 & 9.8 & 19.4 & 19.7 & 27.1 & 13.7 & 19.2 & 15.8 & 22.2 & 19.4 & 11.1 & 28.3 & 14.4 & 9.4 \\
\hline Lipid (g) & 13.3 & 19.8 & 10.5 & 16.1 & 11.6 & 19.7 & 12.7 & 18.6 & 8.6 & 13.9 & 11.3 & 1.8 & 17.6 & 2.5 & 7.5 \\
\hline Carbohydrate (g) & 42.2 & 70.6 & 77.7 & 193.7 & 40.9 & 81.0 & 39.7 & 71.1 & 40.3 & 75.0 & 48.2 & 16.5 & 98.3 & 53.5 & 48. \\
\hline Fiber (g) & 7.0 & 13.6 & 9.1 & 19.8 & 5.3 & 12.7 & 7.4 & 11.2 & 7.3 & 10.4 & 7.2 & 1.3 & 13.5 & 3.6 & 5.4 \\
\hline Iron (mg) & 1.8 & 3.2 & 1.9 & 4.7 & 1.9 & 3.1 & 1.5 & 2.1 & 3.0 & 3.8 & 2.0 & 0.5 & 3.4 & 0.9 & $\begin{array}{c}1.8 \\
\text { Up to }\end{array}$ \\
\hline Sodium (mg) & 2438.7 & 4063.6 & 1707.9 & 2470.4 & 1739.9 & 3462.3 & 2231.0 & 3583.0 & 1550.1 & 2837.9 & 1933.5 & 380.4 & 3283.4 & 630.4 & 400 \\
\hline Vit C (mg) & 39.1 & 39.1 & 118.8 & 398.3 & 12.6 & 14.5 & 41.1 & 41.5 & 39.1 & 39.1 & 50.1 & 40.1 & 106.5 & 163.5 & 7 \\
\hline
\end{tabular}

rice and beans, but differing in protein portion, garnish and fruits. The aim was to compare, from the nutritional point of view, proteins from different sources and various vegetable options. For this, the first menu included ground beef and carrots and the second, a chicken leg and beets.

In both menus, recommendations for energy value and macronutrients (carbohydrates and lipids) were met. However, the amount of protein offered in menus exceeded recommendations. Iron, fiber and vitamin $\mathrm{C}$ reached nutritional recommendations in both menus. Regarding sodium, the value found for this micronutrient, exceeded recommendations established by PNAE.

Menus planned by the municipal dietitian showed a variety of food preparations, requiring the guidance of school meal cooks regarding the portioning of different food preparations as the food groups. For this, a food substitution list was created in a didactic way for the purpose of assisting cooks regarding portion size (Table 4). In the case of preparations with more than one food (i.e. risotto), the size of the proposed portions of each food should be used (risotto - rice: 2 full spoons (90g), Vegetable B-1 full spoon (25g), chicken-1 unit (55g).

\section{DISCUSSION}

Changes in lifestyle and food habits of the population resulting from increasing urbanization in Brazil reinforce the important role of school in the process of formation of healthy eating habits and health promotion ${ }^{6}$. Thus, school is an environment for the development of health promoting actions and nutritional education.

Non-communicable chronic diseases are the main cause of death in Brazil, leading the Ministry of Health to describe the prevention and treatment actions to be taken by the Unified Health System (SUS) ${ }^{7}$. Excess weight, physical inactivity and smoking are some of the main causes for the emergence of NCD and need to be discouraged from childhood and adolescence through global public health actions.

The PNAE plays the role of ensuring the right to adequate food in the context of Food and Nutritional Security and is 
TABLE 3

Proposal for meals that meet PNAE recommendations.

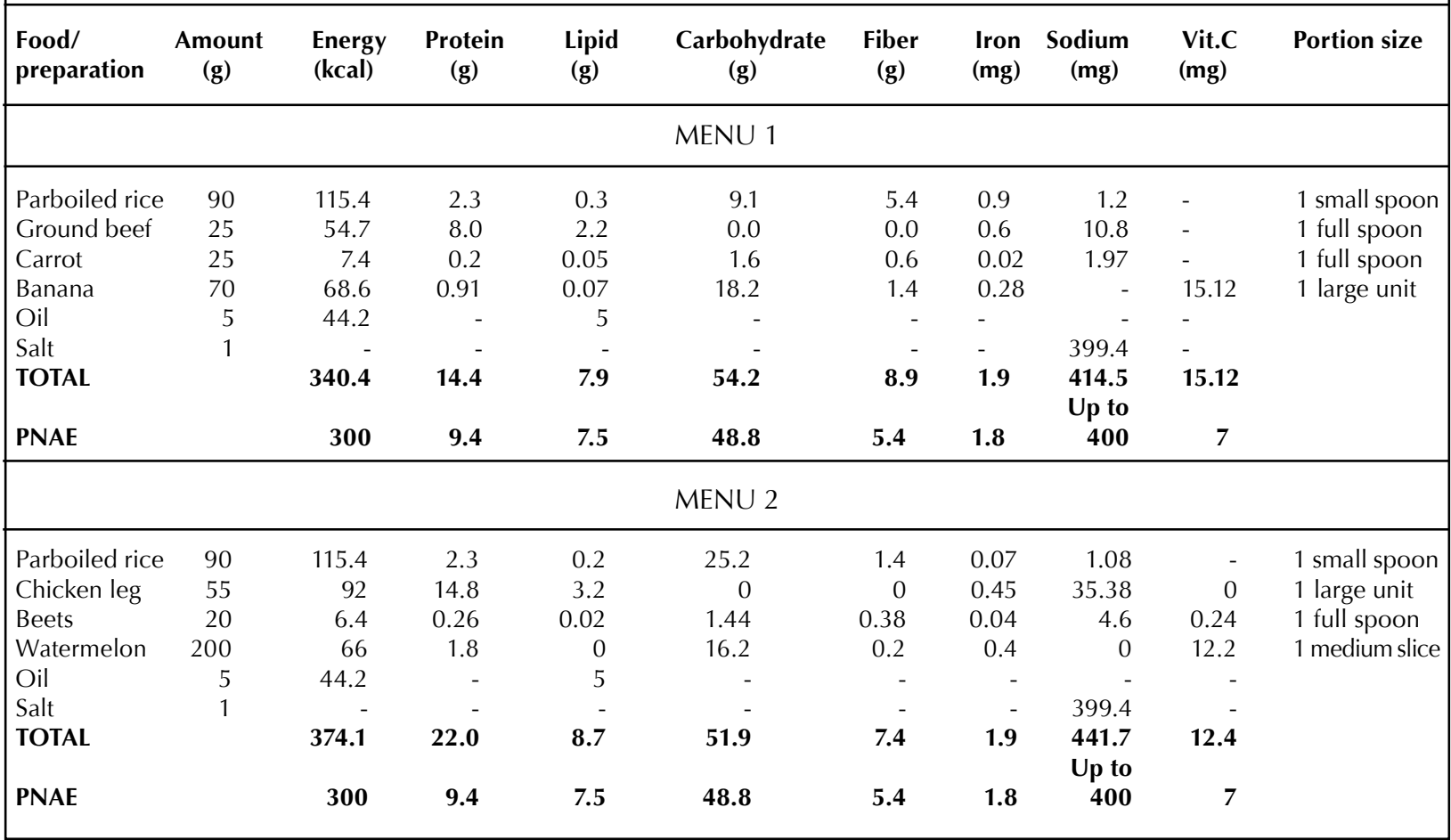

\section{TABLE 4}

Proposal for substitution of food and portion sizes

\begin{tabular}{|l|l|l|}
\hline Food Group & Food preparations & Portion sizes (g) \\
\hline Cereals & Parboiled rice, white rice, pasta & 2 full spoons (90g) \\
Legumes & Black beans, regular beans, chickpeas, lentils & 1 medium spoon (80g) \\
Meats & Ground beef, jerked beef, liver, minced meat. & 1 tablespoon (50g) \\
Chicken & Chicken thigh or drumstick. & 1 unit (55g) \\
Vegetable A & $\begin{array}{l}\text { Lettuce, chard, watercress, cabbage, tomatoes, } \\
\text { zucchini, cauliflower, broccoli, cucumber, eggplant, spinach }\end{array}$ & 1 full spoon (25g) \\
Vegetable B & $\begin{array}{l}\text { Carrot, chayote, pumpkin, beets, onions, peas, } \\
\text { eggplant, okra, green beans }\end{array}$ & 1 tablespoon $(60 \mathrm{~g})$ \\
Vegetable C & $\begin{array}{l}\text { Potato, sweet potato, yam, cassava } \\
\text { Fruits }\end{array}$ & Banana, apple, papaya, melon, orange, pineapple, \\
& tangerine. & \\
\hline
\end{tabular}

responsible for collaborating in the process of student learning and development ${ }^{8}$ and ensuring a minimum food supply to students enrolled in public schools. In this context, the supply of foods/preparations in schools should be appropriate and healthy. Thus, it is necessary to assess whether the meals offered in schools are in line with nutritional recommendations proposed by the PNAE.
In the present study, various changes to the school menu based choices of school meal cooks or service needs were observed, that is, problems in the delivery of some foodstuff, advanced ripening of some fruits, previous day's leftovers, small amount or absence of certain food and difficulty in the pre-preparation of meats, especially on Mondays. These results corroborate other studies that found that seasonality, 
logistics in the supply of foodstuff, preferences for some food preparations by students $\mathrm{s}^{9,10}$, random use of ingredients by school meal cooks 10 and insufficient number of employees ${ }^{11}$ are main reasons for changes in menus designed by the technical staff of schools. The lack of variety of fruits in the menu may contribute to the lower acceptance of this type of food, as their repetition on menu restricts their consumption only for students who like the available option.

In relation to the average values of nutrients analyzed, it must be emphasized that this study found that the portion related to the full measure is offered to the minority of students, and therefore, the portion related to the shallow measure should meet the nutritional recommendations of PNAE.As for the TEV obtained in the present study, the portion related to the shallow measure reached the recommended value for the age group studied. Different results were found by Longo-Silva et. $\mathrm{Al}^{12}$ and Menezes and Osório ${ }^{13}$, who obtained energy values lower than recommendations.

The high protein content in both shallow and full measures corroborates other reports of high consumption of protein present in other publications ${ }^{14,15}$, which show the supply of hyperproteic meals in preschool and elementary schools. Because protein is the most expensive foodstuff, school often provides the main access to meat. In addition, it is an indispensable food in the lunch of Brazilians due to the eating habits of the general population. All these factors lead to hyperproteic meals.

As for lipids, the value obtained in shallow and full measures exceeded recommendations. Different results were found by Conceição et $\mathrm{al}^{16}$, who showed low availability of lipids in the diet of most children enrolled in public schools of São Luís (MA).

Regarding carbohydrates, the suitability of this macronutrient to recommendations provided for PNAE in shallow measure was evidenced; however, the full measure exceeded the recommendation. Similar results were obtained by Flavio et al. ${ }^{17}$, who found high carbohydrate and low-fat contents in the meals of elementary schools of Lavras, Minas Gerais (MG), states of Brazil. It is important to stress the need for adequacy of macronutrients for all age groups, since carbohydrates and primarily lipids are nutrients responsible for providing energy to the body, especially for children.

Dietary fibers are very important for health and prevention of NCD. Thus, the consumption of foods rich in dietary fiber should be encouraged at school. In this study, the amount of dietary fibers met the recommendation for the age group in both measures. This result is largely due to the daily presence of fruit and beans in menus - high-fiber foods - even though the offer of vegetables was inadequate. The difficulty in the supply of raw vegetables is attributed to the lack of structure in the SFNU for their preparation, increasing the microbiological risk. A study by Carvajal et al ${ }^{19}$, however, observed deficiency of dietary fibers in the menu of an elementary school of Maringá - PR, Brazil.

Recommendations for iron and dietary fibers were also met in full and shallow measures. It should be highlighted that iron-rich foods such as liver, offered every two weeks on planned menus are also present. Iron deficiency anemia is common in children, is a public health problem in Brazil, and requires iron-rich diet for its prevention ${ }^{20}$.

Aiming to combat anemia and several highly prevalent nutritional deficiencies in children, the World Health Organization recommends the fortification of foods with micronutrients in order to increase the intake of vitamins and minerals at this stage of life ${ }^{21}$. Recently in Brazil, the Ministry of Health launched a fortification strategy for infant foods with NutriSUS powdered micronutrients, which consists of the daily addition of a sachet rich in vitamins and minerals in one of the meals served in daycare centers ${ }^{21}$. However, the offer of adequate food portions and the variety of food preparations would be sufficient to meet the nutritional recommendations of vitamins and minerals for the various stages of life, as observed in this school.

Regarding sodium, whose PNAE recommendation is up to $400 \mathrm{mg}$ per capita for the partial period, it was observed that its values exceeded by almost five times the maximum allowable value in the shallow measure. Similar result was found by Avozani et $\mathrm{al}^{22}$, who found overconsumption of intrinsic sodium of preparations, without including the addition of salt, by adolescents from public schools of Erechim (RS), Brazil. The fact that sodium had exceeded recommendations is relevant, considering that the only processed food used in the observed day was tuna fish. Therefore, it is reasonable to affirm that a large amount of salt is added by cooks at the time of cooking, when compared to the maximum sodium intake recommended by PNAE.

The high amount of salt used in the preparation of meals can be explained both by the lack of technical preparation data sheets and by the fact that children and adolescents are accustomed to the salty taste on the palate development phase ${ }^{23}$, which follows them in adulthood. Several studies have pointed to sodium restriction as a determining factor for the prevention and control of NCD such as hypertension and diabetes $^{24-26}$, and most importantly, attention to change of the target population for these diseases, which until the twentieth century, was predominantly composed of older adults, but is currently expanding to obese children and adolescents, often before puberty ${ }^{26}$. According to the Federal Nutrition Council resolution $\mathrm{N}^{\circ}$. 465/2010, the creation of technical cards for the preparation of school menus is one of the responsibilities of the dietitian, enabling greater control of salt and oil added to food preparations offered to schoolchildren. The municipality under study did not provide a handbook with technical cards and school cooks determined the amount of spices and foodstuffs in food preparations. There is a great difficulty in elaborating technical cards, as it is necessary to test them in the laboratory in order to determine the portions according to nutritional recommendations. There is also the need to train school cooks and their understanding that they must prepare meals based on them.

The use of natural spices as an alternative to the use of table salt in the preparation of school meals should be 
encouraged. An Australian study showed that reductions of up to $30 \%$ salt does not decrease the acceptability of preparations ${ }^{27}$, a fact that confirms the feasibility of replacing salt by spices and natural seasonings, which can be grown in gardens in the school environment.

Vitamin C content met recommendation in both shallow and full measures, in contrast to the study by Silva et $\mathrm{a}^{15}$. The daily presence of fruits on the menu is a determining factor to meet recommendations for this vitamin, despite the absence of dark green vegetables on menus. Adverse results were observed in another study that showed low consumption of fruits and vegetables in schools, and a large supply of sweets included in menus by industrialized preparations rich in sugar ${ }^{28}$. The present study did not evaluate actual fruit intake by students, since they are offered in the self-service system, and therefore it cannot be affirmed that all students met recommendations for this vitamin. However, the offer of sweets and industrialized preparations for dessert was not observed in this school during the study period.

The 2008-2009 Family Budget Survey ${ }^{29}$ demonstrated that the Brazilian population does not consume adequate amounts of vegetables and especially fruits. The 2009 National School Health Survey ${ }^{30}$ showed low consumption of fresh fruits by 9 th grade students of public and private schools in Brazil. In this sense, the school plays the role of supplying fruits and vegetables in order to solidify good eating habits through FNE actions and encourages the consumption of healthy food by children who do not have access to them in their homes.

Menu proposals have been made in order to meet PNAE nutritional recommendations, as well as the propositions in the Food Guide for Brazilian population ${ }^{31}$, regarding the promotion of healthy eating habits, sodium intake restriction and reduced consumption of minimally processed and ultraprocessed foods.

The proposed menus were in agreement with PNAE nutritional recommendations, except for sodium, which was slightly above recommended values, adding, on average, $1 \mathrm{~g}$ of salt in the preparation of meals. However, research is needed to assess the acceptability of meals regarding the amount of salt proposed, as some studies have found that average salt added is much higher than recommended values ${ }^{32,33}$.

It is important to emphasize the need to evaluate the portion sizes of preparations to the reality of children, since very high portion sizes of chicken or beans would not be consumed by students, and therefore have not been calculated in theory.

High protein levels were observed due to the same reasons, i.e., protein-rich foods are the most expensive foodstuff - and in many cases, the main access to them is in school, and for the preference for meat verified in the food habits of Brazilians, which together characterize hyper-proteic meals in this population. Moreover, iron recommendations in both menus is a further justification for this result, since foods rich in iron are generally rich in protein, such as meat and beans.
Thus, this study points to the importance of the right provided in the Constitution to adequate and healthy food, and the difficulty of achieving nutritional recommendations due to the entire process involved in school meals, from obtaining foodstuffs to the distribution of food preparations by school cooks.dardization of portion sizes of foods/dishes offered in school, so that the recommendations of macro and micronutrients are met and are not exceed as observed in schools. The importance of training school lunch cooks, since they are responsible for the portioning of preparations offered in schools, is also noted. It is possible to highlight some themes that can be used in the training of school lunch cooks to guarantee the standardization of food portions, namely: the importance of standardization among school lunch cooks; difficulties in the workplace such as standardization and the practice of preparations through the proposal for substitution of food and portion sizes, and the elaboration of a photographic record of the food preparation to be made available in schools.

\section{CONCLUSIONS}

The school menu showed divergence from the planned menu by the responsible dietitian of PNAE. Although they are common in the daily life of schools for various reasons, such changes are worrying as they may compromise the offer of varied food, contributing to food monotony.

With portion sizes based on shallow measures of preparations/foods, the PNAE recommendations in relation to TEV, carbohydrates, lipids, dietary fiber, iron and vitamin C were achieved; protein and sodium exceeded the recommended values. Moreover, portioning based on the full measures exceeded TEV, proteins, lipids, carbohydrates and sodium.

Based on these findings, this study points to the need to elaborate manufacturing technical cards aimed to standardize the portioning of foods/dishes offered to schoolchildren, as well as the training of school meal cooks in adequate portion sizes.

Conflict of interests: The authors declare that they have no conflict of interests.

Financial support of Fundação Carlos Chagas Filho de Amparo à Pesquisa do Estado do Rio de Janeiro.

\section{RESUMEN}

Verificar si el tamaño de las porciones adoptadas por los cocineros de los almuerzos escolares está de acuerdo con las recomendaciones nutricionales del PNAE (Programa Brasileño de Nutrición Escolar). Los tamaños de las porciones correspondientes a mediciones, poco profundas y completas, se pesaron en una balanza digital para determinar el peso promedio de cada porción de alimento. Se comparó el valor energético total (VET), carbohidratos, proteínas, lípidos, hierro, sodio, vitamina $C$ y fibra dietética con las recomendaciones de PNAE para escolares. Como resultado, se desarrollaron dos propuestas de menú con la adecuación del tamaño de las porciones. Las recomendaciones VET y carbohidratos se 
cumplieron en el tamaño de la porción relacionada con la medida poco profunda. Tanto las mediciones poco profunda y completas superaron las recomendaciones de proteínas, grasas y sodio. Los valores encontrados para fibra dietética, hierro y vitamina $C$ alcanzaron las recomendaciones de PNAE en ambos tamaños de porciones. Las propuestas de menús alcanzaron las recomendaciones nutricionales excepto el sodio, que se mantuvo ligeramente por encima de los límites. Es necesario elaborar tarjetas técnicas de fabricación con el objetivo de estandarizar la porción de alimentos que se ofrece a los escolares, así como la capacitación de cocineros. Palabras clave: Programa Brasileño de Nutrición Escolar, escolares, menús, recomendaciones nutricionales.

\section{REFERENCES}

1. Brasil. Ministry of Education. National Fund of Education Development. Ministry of Education. Resolution/CD/FNDE $n^{\circ} 38$, from July 19, 2009. Provides the supply of food for primary students in the National School Feeding Program.

2. Da Rosa C\& Miraglia F. Evaluation of menus in schools of the municipal network of Alvorada / RS and comparative analysis with the Brazilian Food Guide. Cippus 2013; 2: 130-138.

3. Vitolo MR. Nutrition: from gestation to aging. $2^{a}$ ed, Rio de Janeiro, Rúbio, 2008.

4. Universidade Estadual de Campinas. Núcleo de Estudos e Pesquisas em Alimentação. Brazilian table of food composition, 2. ed, Ed. UNICAMP, p.113. 2006. Avaiable: www.unicamp. $\mathrm{br} /$ nepa/taco

5. Pinheiro ABV, Lacerda EMA, Benzecry EH et al., Table for evaluation of food consumption in home measures. $5^{\mathrm{a}} \mathrm{ed}$, Atheneu, 2008.

6. Schmitz BA, Recine E, Cardoso GT, da Silva JR, Amorim NF, Bernardon $R$, Rodrigues ML. The school promoting healthy eating habits: a methodological proposal of training for educators and school canteen owners. Cad Saúde Pública 2008; 24: 312-22.

7. Brasil. Ministério da Saúde. Surveillance, control and prevention of chronic noncommunicable diseases at the context of the Brazilian Health System / Brazil. Ministério da Saúde, Organização Pan-Americana da Saúde, 2005.

8. Belik W \& Chaim NA. The National School Feeding Programme and municipal management: administrative efficiency, social control and local development. Rev Chil Nutr. 2009; 22: 595-607.

9. Pecorari RCF. A proposal of innovation in the school menu based on the evaluation of the School Feeding Programme of Piracicaba-SP. São Paulo. Dissertação [mestrado] - Universidade Estadual Paulista, Faculdade de Ciências Farmacêuticas, 2006.

10. Issa RC, Moraes LF, Francisco RRI, Santos LC, Anjos AFV, Pereira SCL. School feeding: planning, production, distribution and adequacy. Rev Panam Salud Publica 2014; 35: 96-103.

11. Belik W \& Domene SMA. Experiences of combined school feeding and local development programs in São Paulo - Brazil. Agroalimentaria 2012; 18: 57-72.

12. Longo-Silva G, Toloni MHA, Menezes RCE et al. Ingestion of protein, calcium and sodium in public day care centers. Rev Paul Pediatr 2014; 32: 193-199.

13. Menezes RCE \& Osório MM. Energy-protein intake and nutritional status of children under five in the state of Pernambuco, Brazil. Rev Nutr 2007; 20: 337-347.
14. Valente TB. Food and nutritional profile of preschool children assisted by an institutional nursery in the city of Santa Maria, RS. Santa Maria. Dissertação [mestrado] - Universidade Federal de Santa Maria, 2009.

15. Silva RG \& Fernandes TF. Nutritional value of snacks offered at a municipal school in rural Pernambuco. Rev. Baiana Saúde Pública 2014; 38: 404-16.

16. Conceição SIO, Santos CIN, Silva AAM et al., Food consumption of schoolchildren in public and private schools in São Luís, Maranhão. Rev Chil Nutr 2010; 23: 993-1004.

17. Flávio EF, Barcelos MFP, Cirillo MA et al., Evaluation of school feeding offered to elementary school students in the municipal schools of Lavras, MG. Ciênc Agrotec 2008; 32: 879-887.

18. Neitzke L, Molina MCB, Salaroli LB. Nutritional adequacy of school feeding in a rural municipality - Espírito Santo, Brazil. Nutrire 2012; 37: 1-12.

19. Carvajal AESS, Koehnlein EA, Bennemann RM. Evaluation of the lunch of a Municipal School from 1 to 4 series Maringá PR. In: VI EPCC Encontro Internacional de Produção Científica Cesumar. Maringá: Centro Universitário de Maringá, 2009.

20. Jordão RE, Bernardi JLD, Barros FAA. Prevalence of iron deficiency anemia in Brazil: a systematic review. Rev Paul Pediatr 2009; 27: 90-98.

21. World Health Organization. Guideline: Use of multiple micronutrient powders for home fortification of foods consumed by infants and children 6-23 months of age. Geneva, WHO, 2011.

22. Ministry of Health. School Health Program (PSE). NutriSUS. Brasilia, Ministry of Health, 2014. http://dab.saude.gov.br/ portaldab/pse.php? Conteudo= nutrisus.

23. Avozani P, Spinelli RB, Zemolin GP et al., Evaluation of Sodium Intake and the Risk of Arterial Hypertension in Adolescents of the Public Schools of Erechim - 24. Jesus DC \& Gonçalves ECBA. The consumption of processed foods in children's diet and high blood pressure. Nutr Brasil 2012; 11: 22-25.

25. Costa FP \& Machado SH. Consumption of salt and sodiumrich foods may influence children's blood pressure? Ciênc Saúde Col 2010; 15: 1383-1389.

26. Nishimura RY, Damião R, Gimeno SGA et al., Food Groups for Risk Research for Type 2 Diabetes and Associated Diseases. Rev Bras Epidemiol 2011; 14: 531-536.

27. Ferreira JS \& Aydos RD. Prevalence of hypertension in obese children and adolescents. Ciênc. Saúde Col 2010; 15: 97-104.

28. Cobcroft M, Tikellis K, Busch J. Salt Reduction - a Technical Overview. Food Australia 2009; 9: 29-31.

29. Menegazzo M, Fracalossi K, Fernandes AC et al., Qualitative evaluation of the menu preparations of early childhood centers. Rev Chil Nutr 2011; 24: 243-251.

30. Instituto Brasileiro de Geografia e Estatística - IBGE. Family Budgets Survey, 2011 http://www.ibge.gov.br/home/xml/ pof_2008_2009.shtm.

31. Instituto Brasileiro de Geografia e Estatística - IBGE. Pesquisa Nacional de Saúde do Escolar, 2009.

32. Departamento de Atenção Básica, Secretaria de Atenção à Saúde, Ministério da Saúde. Food Guide for the Brazilian Population. 2a ed, Brasília, Ministério da Saúde, 2014.

33. Department of Basic Attention, Secretariat of Health Care, Ministry of Health. Food Guide for the Brazilian Population. $2^{a}$ ed, Brasilia, Ministry of Health, 2014.

33. Paiva I, Pinto C, Queiros L, et al., Low calorie and high salt content in meals served in school canteens. Acta Med Port 2011; 24: 215-222. 